DOI: 10.18276/psw.2016.1-03

\begin{abstract}
Alicja Żywczok
Uniwersytet Śląski

\section{Postawa skromności - czynnik dynamizujący rozwój naukowy}

\title{
Wprowadzenie
}

Postawa skromności ${ }^{1}$, czyli przeciwieństwo pychy i megalomanii, jest szczególnym wymogiem stawianym pracownikowi naukowemu, świadectwem jego mądrości, predyspozycji do poznawania prawdy i uczciwego komunikowania rezultatów badań. Na podstawie wyników własnych badań biograficznych ${ }^{2}$ w artykule wysunęłam i uzasadniłam tezę, że głównymi czynnikami indywidualnego rozwoju naukowego, oprócz intelektualnych, sa atrybuty osobowościowe, takie jak skromność. Rozwój naukowy jest wspomagany głównie przez wyznawane wartości i odpowiadające im cechy charakteru (vs osobowości) badacza. Przyjęłam również założenie, że za pośrednictwem procesu rozwoju naukowego uczonych dokonuje się postęp w nauce rozumianej jako dziedzina kultury.

Postawa pokory wynika m.in. $z$ faktu, że uczeń ma zawsze jakiegoś mistrza, któremu zawdzięcza swój rozwój (lub przynajmniej inspirację), a nawet jeśli nie mistrza, to nauczyciela wdrażajacego adepta $\mathrm{w}$ tajni-

${ }^{1}$ Człowiek skromny - 1. Powściąliwy, niewymagający, niedbający o rozgłos, niedumny, zwyczajny, odznaczający się prostotą; będący wyrazem takich cech. 2. Niemający dużych dochodów, majętności; niebogaty; nieprzynoszący dużych zysków. Na użytek niniejszego artykułu skorzystałam głównie $z$ pierwszego rozumienia skromności - Mały słownik języka polskiego, red. S. Skorupka, H. Auderska, Z. Łempicka, Państwowe Wydawnictwo Naukowe, Warszawa 1968, s. 751.

2 Posługujac się hermeneutyczna interpretacja treści w ramach metody biograficznej - biografii tematycznej, w latach 2007-2009 przeanalizowałam pięćdziesiąt sylwetek uczonych $z$ różnych krajów, przedstawicieli wielu dyscyplin nauki. Badania biograficzne kontynuowałam w latach 2013-2015, poddając wnikliwej analizie dwadzieścia kolejnych postaci naukowców. Badanie opublikowanych dokumentów osobistych, takich jak listy, pamiętniki, dzienniki, wspomnienia, zapiski i notatki, a przede wszystkim biografie i autobiografie, dostarczyło obszernego materiału badawczego stanowiącego skarbnicę wiedzy o procesie rozwoju naukowego i jego najistotniejszych „katalizatorach”. 
ki pracy badawczej. To jest już wystarczającym powodem, by zachować umiar w pozytywnej autoprezentacji. Pokory uczy także świadomość, iż na obecny stan rozwoju nauki pracowały pokolenia znakomitych poprzedników, w stosunku do których ludzie współcześni powinni odczuwać wdzięczność ${ }^{3}$. Działalność naukowa jako jedna $z$ form konfrontacji człowieka ze światem wymaga, zdaniem Ferdynanda Gonsetha, czujności etycznej i respektowania humanistycznych wartości. Tak pojmowana nauka wskazuje społeczeństwu kierunek budowania wspólnoty zarazem intelektualnej i moralnej4 .

Ważne dla postępów nauki oraz satysfakcji z wykonywanego zawodu uczonego jest to, by nie próbowano zdetronizować kogoś, kto uprawia swa naukę inaczej, starajac się w ten sposób być pomocnym społeczności. Nie należy zapominać, że ludzie nauki w jej zdobyczach znajduja słodycz życia ${ }^{5}$, a nawet jego sens. Eksponowanie siebie stanowi w profesji naukowca (zwłaszcza recenzenta) pokusę, której służa rozmaite zabiegi komunikacyjne i retoryczne. Skupienie się wyłącznie na odbiorcach, których wręcz prowokuje się do okazywania przejawów poważania, staje się czasem głównym motywem działalności naukowej, prowadzac do zaniedbywania istotnych poznawczo zadań. Deficyt skromności można uznać zatem za czynnik zagrażający dynamicznemu rozwojowi naukowemu.

\section{Skromność - rezultat wysokiej samoświadomości i autokrytycyzmu}

Uczeni należą do grupy, która prawdopodobnie najlepiej wie, czego nie wie, a taka samoświadomość rodzi określony rodzaj postawy godnościowej polegającej na roztropnym usytuowaniu człowieka wśród innych bytów, czyli odpowiednim postrzeganiu siebie (adekwatnie chociażby do swych fizykalnych rozmiarów). Już antropologiczna koegzystencja skłania go do przyjęcia postawy zdumienia makrokosmosem, szacunku i pokory.

3 A. Żywczok, Aksjologia odkrycia naukowego - studium rozwoju i wychowania osobowości naukowych, Wydawnictwo Adam Marszałek, Toruń 2009, s. 124.

${ }^{4}$ L. Witkowski, Filozofia nauki Ferdynanda Gonsetha na tle problemów współczesnego racjonalizmu, Wydawnictwo Uniwersytetu Mikołaja Kopernika, Torun 1983.

5 Ch. Garwe, Rozprawy popularnofilozoficzne, przekł. R. Kuliniak, T. Małyszek, Wydawnictwo Uniwersytetu Wrocławskiego, Wrocław 2002, s. 45, 54. 
Na konieczność zachowania równowagi między dumą a pokora zwrócił uwage m.in. Dawid Hume:

Duma i pokora, choć sobie przeciwne, mają ten sam przedmiot - nasze „ja”. [...] Gdy „ja” nie wchodzi w zakres rozważania, nie ma miejsca ani na dumę, ani na pokorę. Duma podnosi nasze poczucie, pokora je obniża. Cudza pokora podnosi nasze samopoczucie, natomiast cudza duma nas upokarza. Najbardziej oczywista przyczyną i godna uwagi własnościa jest to, iż mogą one dotyczyć bardzo wielu rzeczy. Każda wartościowa własność umysłu, czy to wyobraźnia, władza sądzenia, pamięć, temperament, dowcip, zdrowy rozsądek, erudycja, odwaga, sprawiedliwość, prawość - wszystkie te rzeczy sa przyczynami dumy, a ich przeciwieństwa przyczynami pokory. Nasz kraj, rodzina, związki pokrewieństwa, dobra: domy, ogrody, konie, ubiory - każda $z$ tych rzeczy może się stać przedmiotem bądź dumy, bądź pokory ${ }^{6}$.

John H. Newman zachęca do powstrzymywania siebie i innych przed pomnożeniem takich przywar, jak pycha. W swych Kazaniach Uniwersyteckich pisze:

Takie jest oddziaływanie niepohamowanej pychy - wpierw doprowadza nas do upojenia się nieograniczona wolnościa woli i postępowania, a następnie, gdy zniszczymy już samych siebie, argumentuje, że jesteśmy niewolnikami konieczności [...]. Pokusa pychy polega na pewnego rodzaju przewrotności w naturze ludzkiej, opartej na niejasnym poczuciu wielkiego znaczenia własnej osoby ${ }^{7}$.

Pokora wystawia człowieka na ataki innych, duma - wprawdzie od ludzi odgradza, ale częściowo również przed nimi chroni. Konstatacja ta prowadzi do sądu, że ludzie nauki, uznawani za osoby publiczne, moga doświadczać licznych ataków ze strony otoczenia, ale nie są wobec nich bezwolni. Bronia okazuje się, w mym przekonaniu, umiejętne zespolenie w psychice człowieka pokory i dumy manifestujące się w zachowaniu zgodnym z zasadami rozwagi. Rozsądek chroni przed próżnością i zuchwalstwem, a odrobina uzasadnionej dumy z drobnych powodzeń do-

${ }^{6}$ D. Hume, Traktat o naturze ludzkiej, t. 2, przeł. Cz. Znamierowski, Polska Akademia Umiejętności, Kraków 1952, s. 3, 5, 21.

7 J.H. Newman, Kazania uniwersyteckie. Piętnaście kazań wygłoszonych przed Uniwersytetem Oksfordzkim między 1826 a 1843 rokiem, przeł. P. Kostyło, Wydawnictwo „Znak”, Kraków 2000, s. 138, 157. 
daje dostojeństwa i wiarygodności. Pokora nie zawsze jest przykra, tak jak duma niekoniecznie przyjemna. Ważniejsze jest jednak, by zarówno duma, jak i pokora były moralnie i etycznie uzasadnione oraz by doprowadziły do rozwoju człowieczeństwa i dojrzałości naukowej pracowników naukowych.

Naukowiec musi mieć dość dużo zaufania do siebie, by przeprowadzać wielkie przedsięwzięcia, a przy tym być dostatecznie skromnym, aby bez rozczarowania zdać sobie sprawę, że życiowej chwały prawdopodobnie nie zdobędzie. Musi on wierzyć nie tylko w naukę w ogóle, ale również we własną wiedzę. Kiedy dokonuje eksperymentu lub dowodzi czegoś, powinien mieć zaufanie do swej siły intelektualnej. Skromność łagodzi megalomanię naukowca w ściśle określonym celu: po to, by mógł realizować swój projekt badawczy, skupiając się głównie na jakości pracy naukowej. Niektórzy uczeni tak chorobliwe pożądaja aplauzu, że spędzają większa część czasu na próbach zwrócenia uwagi otoczenia na swe osiagnięcia. Jedyna pokrewna forma postępowania, równie odrażajaca, jest skromność na pokaz. Prawdziwa skromność pozostaje wewnatrz; człowiek skromny nie ściaga uwagi otoczenia na własna skromność. Naprawdę „wielcy” ludzie sa zbyt uczciwi, aby udawać skromność, i za skromni, aby swą skromnościa popisywać się publicznie. Chociaż są dumni z rezultatów własnej pracy, to dbaja o to, by nie wyolbrzymiać jej znaczenia. Sa na tyle pograżeni w swoich dociekaniach, że nie traktują własnej skromności jak eksponatu ${ }^{8}$.

Edith Stein, filozof fenomenolog, przedwcześnie zgładzona w obozie w Oświęcimiu, tak opisuje stosunek wobec efektów własnej pracy naukowej:

Świadomość własnej ograniczoności uczyniła we mnie w ostatnich miesiącach wielkie postępy. Brak tej świadomości oznaczał, w moim przypadku, nieco naiwna wiarę w siebie. Teraz, gdy jestem w ciagłym kontakcie $z$ ludźmi wrośniętymi w swoja pracę, odpowiednio przygotowanymi i wykształconymi, widzę, że niedomagam na każdym odcinku. Ta świadomość właściwie mnie nie deprymuje, nie jest jednak łatwo stać na tak odpowiedzialnej placówce $z$ takimi brakami i tak słaba nadzieją ich wyrównania. Skoro jednak okoliczności przemawiaja za tym, że jestem tu $z$ Boska pomoca, chyba nie wolno mi teraz dezerterować ${ }^{9}$.

8 H. Selye, Od marzenia do odkrycia naukowego. Jak być naukowcem, przeł. L. Zembrzuski, W. Serżysko, Państwowe Zakłady Wydawnictw Lekarskich, Warszawa 1967, s. 155.

9 E. Stein, Pisma, t. 2, Wydawnictwo Karmelitów Bosych, Kraków 1982, s. 160-161. 
Tendencję do surowej samooceny, a równocześnie poddawania się uważnej krytyce naukowej, można dostrzec również w innym liście Edith Stein do Jadwigi Conrad-Martinus:

Gdyby Pani zechciała się tego podjąć, chętnie bym [...] przesłała to monstrualne dzieło do ostrej krytyki i bezwzględnej oceny, gdyż nieraz już zapytywałam siebie, czy praca filozoficzna w ogóle nie przerasta moich możliwości. Myślę, że ta wattpliwość pozostała we mnie $z$ czasów, gdy Lipps skrytykował radykalnie moją wielka pracę $\mathrm{w} \mathrm{V}$ tomie Rocznika, a jednocześnie Pani Reinach usiłowała mi wytłumaczyć, że braki w mojej pracy pochodza $z$ wielu głęboko we mnie tkwiących niedostatków osobistych. To wszystko wówczas ogromnie mnie przygnębiło, może $z$ tej przyczyny, że tego nie rozumiałam. W latach, gdy zupełnie nie myślałam o pracy filozoficznej, nie miałam oczywiście powodu do niepokoju. I teraz właściwie też go mieć nie mogę, ale skoro staję przed tak wielkim zadaniem, zależy mi, aby wiedzieć jasno, na co rozsądnie mogę się odważyć10.

Karl Popper, człowiek niezwykle rzetelny intelektualnie, a zarazem powściagliwy w pozytywnej autoprezentacji, jak uważają ci, którzy zetknęli się z nim bezpośrednio, w swojej Autobiografii intelektualnej pisał:

Nauczyłem się nigdy nie bronić niczego, co napisałem przed zarzutem niejasności. Jeżeli sumienny czytelnik stwierdza, że coś jest niejasne, należy to napisać na nowo. Tak nauczyłem się nieustannego upraszczania i rozjaśniania swoich prac [...]. Ludzkość nie może zaprzestać poszukiwania prawdy, ale musi strzec się złudzenia, że jest w stanie prawdę zdobyćc ${ }^{11}$.

Połączenie umiejętności rozumienia innych $z$ pokora ujawnia się w jego antydogmatycznych przekonaniach naukowych, które stanowiły wyróżnik wielu ludzi nauki.

Życie naukowe uświadomiło mi mąrość Sokratejskiego powiedzenia: wiem, że nic nie wiem i zaszczepiło wiarę w wartość intelektualnej skromności. Uświadomiło mi głębokie różnice, jakie zachodza pomiędzy myśleniem dogmatycznym a krytycznym. [...]. Czułem, że na tym polega postawa prawdziwie naukowa. Jest ona skrajnie odmienna od postawy dogmatycznej takich myślicieli, jak: Marks, Freud czy Adler,

10 Ibidem, s. 172-173.

11 K. Popper, Nieustanne poszukiwania. Autobiografia intelektualna, Wydawnictwo „Znak”, Kraków 1997, s. 114, 7. 
którzy głosili, że znaleźli weryfikacje dla swych ulubionych teorii. Doszedłem do wniosku, że postawa naukowa to postawa krytyczna, która nie poszukuje weryfikacji, lecz krzyżowych rozstrzygnięć - sprawdzianów, które mogą obalić sprawdzaną teorię, lecz nigdy nie moga jej udowodnić ${ }^{12}$

Zarówno wątpliwości człowieka, jak i poszukiwanie pewności stanowia ważne czynniki rozwoju nauki. Fluktuacja w psychice uczonego wątpienia i nieustępliwego poszukiwania pewności współtworzy osobliwe warunki wyrażania mądrości. Kartezjańskie „wątpię więc myślę...” usytuowane przed „myślę więc jestem” nie jest przypadkowe; wyraża istotę rzeczy. Watpienie stanowiące „źródło” kultury i cywilizacji nie jest jednak nawykowym kwestionowaniem każdej opcji myślowej lub aksjologicznej, a raczej poddawaniem rozumnemu namysłowi wszystkiego, co znaczace dla ludzkiego istnienia.

Prawdziwa mądrość tkwi w wielu wątpliwościach, człowiek zaś jako istota wątpiąca może czynić to na sposób jej właściwy, czyli mądry. Taka koncepcja ludzkiej kondycji poznawczej jest zwiazana $z$ tolerancja i dobra wolą, uczy skromności i powściagliwości, gdyż przeświadczenie o własnej omylności i niepewność własnej mądrości może powstrzymać ludzi przed popełnieniem błędów wynikających $z$ pychy. Jest to pogląd, który wydaje się dość oczywisty, wręcz zbanalizowany, lecz bywa tak rzadko wprowadzany w życie ${ }^{13}$, również w codzienność społeczności akademickiej, że warto chyba stale do niego powracać. Można się zgodzić z poglądem Andrzeja Grzegorczyka, że:

Brak watpliwości i niepokojów intelektualnych wynika $z$ dążenia do stanu nazywanego komfortem psychicznym bądź wygodą. Zapewnia go złudna wiara $\mathrm{w}$ niezawodność teorii naukowej bądź umiejętność wybrnięcia $z$ niemal każdej sytuacji za pomoca przyjętej retoryki. Taki stan daje zadowolenie, jednak często powoduje zatracenie krytycyzmu i dociekliwości badawczej ${ }^{14}$.

12 Ibidem, s. 51, 53.

13 Z. Bauman, K. Tester, O pożytkach z watpliwości. Rozmowy z Zygmuntem Baumanem, Wydawnictwo „Się”, Warszawa 2003, s. 67, 49.

14 A. Grzegorczyk, Motywacje zakłócajace proces poznawczy, w: Etyka zawodowa ludzi nauki, red. J. Goćkowski, K. Pigoń, Państwowy Instytut Wydawniczy, Wrocław-WarszawaKraków 1991, s. 84. 
Mikołaj Kopernik przewidując rewolucję umysłowa wywołana jego teoria heliocentryczna, w Liście do Ojca Świętego Pawła III zasiadającego na stolicy apostolskiej w latach 1534-1549, znanego $\mathrm{z}$ wszechstronnego wykształcenia i zainteresowania sztuka, literatura i nauka, pisał:

Dostatecznie jasno zdaję sobie sprawę z tego, że znajdą się ludzie, którzy gdy tylko posłysza, iż w tych moich księgach o obrotach sfer wszechświata przypisuję jakiś ruch kuli ziemskiej, zaraz podniosą krzyk, iż należy mnie wraz $z$ takim przekonaniem potępić. Nie jestem bowiem do tego stopnia zakochany we własnym dziele, żebym nie zważał na to, co o nim będą sądzić inni. [...] Myśli uczonego są jednak niezależne od sądu ogółu, ponieważ dążeniem uczonego, o ile tylko rozumowi pozwala na to Bóg, jest szukanie we wszystkim prawdy ${ }^{15}$.

Niezależność uczonego od opinii ogółu czyni go pokornym również wobec odkrytej prawdy. Uczniowie i współpracownicy Stefana Wołoszyna, polskiego historyka wychowania, wskazują na niepospolita kulturę osobista Profesora, na która składała się między innymi omawiana postawa skromności:

Kiedy zwróciłem się do mych przyjaciół korczakowców z prośba - podajcie mi najważniejsze cechy Profesora Wołoszyna - bez większego zastanowienia i zgodnie podano następujące: odpowiedzialny, cichy, skromny, zawsze gotowy do pomocy, życzliwy ludziom [...]. Ujmująca skromność Profesora obserwujemy zarówno w oficjalnych, jak i nieoficjalnych kontaktach, w trybie i stylu jego życia. Kiedy mówiono: niezawodność czy punktualność, wiemy $z$ doświadczenia, że nigdy im nie uchybił ani w sprawach wielkich, ani małych. Każdy, kto zwrócił się do Profesora, mógł być pewien, że zostanie uważnie wysłuchany, a na korespondencję czy przesłany tekst otrzyma przyjazną odpowiedź. Życzliwość pojmuje Profesor jako służbę ludziom, toteż nie wyklucza ona surowej, choć zawsze eleganckiej krytyki; przeciwnie - stanowi jej element obowiązkowy. [...] Nie było dla Profesora zebrań mniej lub bardziej ważnych - na każde przychodził nie szczędząc dobrych porad i sugestii. Były to zawsze sugestie - nigdy odgórne polecenia $z$ pozycji profesorskiej nadrzędności. [...] Jako autentyczny humanista Profesor miał też czas dla swoich pasji pozanaukowych. Dzielił się z nami wrażeniami np. po obejrzeniu ciekawej sztuki teatralnej. Traktowaliśmy to jako subtelne przypomnienie, że nie sama pracą człowiek żyje. Pamiętam, że kiedyś niemal przez cały czas drugiej części zebrania katedry rozmawialiśmy

15 Za: C. Iwaniszewska, Astronomia Mikołaja Kopernika, Wydawnictwo Towarzystwa Naukowego w Toruniu, Toruń 1994, s. 26. 
na temat krakowskiego kabaretu „Piwnica pod Baranami”, z okazji jego gościnnego wyjazdu do Stolicy. W latach 1969-1970 niektóre popołudniowe zebrania katedry odbywały się w szczególnej dyscyplinie czasowej, aby można było obejrzeć transmisje telewizyjne $z$ meczów pucharowych „Górnika” Zabrze i „Legii” Warszawa. Nieraz Profesor oglądał mecz piłkarski na stadionie „Legii”. [...] Stefan Wołoszyn swoja postawa potwierdził tezę, że w nie mniejszym stopniu wychowuje się przez to, kim się jest, niż przez to co się wie i potrafi [...]. Rozległość wiedzy, fenomenalna pamięć oraz doskonała kondycję intelektualna i fizyczną Profesor łączył z pełną uroku skromnościa. Świetne referaty, które wygłasza na wielu konferencjach naukowych, zawieraja najczęściej podtytuł: "Głos w dyskusji”, chociaż treść tych wypowiedzi podejmowała fundamentalne dla przedmiotu obrad problemy, a sposób myślenia Profesora zmieniał kierunek rozumowania dyskutantów. A słynna teczka Profesora Wołoszyna? Zawsze ta sama od wielu lat, wybielała $z$ wysługi ludziom i nauce. Zawsze dla siebie niewiele, a dla innych bez miary. Nigdy też nie budował swego autorytetu kosztem innych, przeciwnie, narażał swój autorytet chroniąc podopiecznych i ich rzeczywiste, perspektywiczne interesy ${ }^{16}$.

Analiza biografii i autobiografii naukowców pozwala na stwierdzenie, że w życiu uczonych również zainteresowania pozanaukowe pełnia wiele istotnych funkcji: chronia przed nadmiarem wiedzy encyklopedycznej, pozwalaja zdystansować się do własnych prac naukowych, regeneruja siły somatyczne i psychiczne, a ponadto stanowią ważne źródło stricte naukowych inspiracji (rodza nowe asocjacje).

Nie tylko portrety psychologiczne naukowców przekonuja do przyjęcia osobliwej postawy skromności, pokory „ucza” także teorie naukowe, spośród których wyróżniającymi pod tym względem są: heliocentryczna teoria Kopernika i teoria ewolucji Darwina. Zmieniły one radykalnie pozycję człowieka w kosmosie; jego miejsce wśród innych organizmów żywych. Edukacja młodego pokolenia naukowców ma przecież zasadniczo kilka celów: wolność od ignorancji, nieznajomości praw uniwersum i uprzedzeń. O ile tak zarysowuje się rozwój zarówno nauki, jak i człowieczeństwa, o tyle niebagatelne na tej drodze sa elementarne czynniki, takie jak wdzięczność i pokora, będące przeciwieństwem poczucia własnej nieomylności.

16 Z. Żukowska, Stefan Wołoszyn. Pedagogiczne wędrówki przez wieki i zagadnienia. Studia $i$ szkice, Wydawnictwo Adam Marszałek, Warszawa-Toruń 1996, s. 18, 250, 252253, 255, 261-262. 


\section{Skromność pracownika naukowego - przeszkoda epistemiczna czy facylitator?}

Skromność wielu ludzi nauki nie była związana na ogół z ich nieśmiałościa, wewnętrznym skrępowaniem czy poczuciem małej wartości, zależała raczej od pokory wobec wszechświata i jego największych, a zarazem najbardziej obiecujaccych tajemnic. Prawdziwa skromność bowiem wyklucza przeobrażenie osoby i osobowości w niedostępną osobistość.

Niebywała skromność Alberta Einsteina opisywał Karl Popper, ujęty urokiem osobistym tego wielkiego uczonego:

Trudno jest opisać wrażenie, jakie wywierała na mnie osobowość Einsteina. Być może da się je wyrazić stwierdzeniem, że w jego towarzystwie natychmiast czuło się jak u siebie w domu. Nie można mu było nie ufać, nie polegać na jego prostoduszności, życzliwości, zrównoważeniu, mądrości i niemal dziecięcej prostocie. Dobrze to świadczy [...] o Ameryce, że człowiek zupełnie nie $z$ tego świata nie tylko przetrwał, ale został doceniony i tak bardzo uhonorowany ${ }^{17}$.

Jan Władysław Dawid, pedagog i psycholog, sprawiał wrażenie człowieka oderwanego od spraw codziennych, a to wrażenie potęgowało się pod wpływem jego duchowej nieobecności - zarówno wobec słuchaczy, jak i w jego stale gwarnym mieszkaniu. Skromność i zażenowanie widoczne były szczególnie wyraźnie, gdy zmuszony był porozumiewać się $z$ innymi. Prawdopodobnie $z$ tego powodu, poza systematycznymi wykładami na uczelni, Dawid przemawiał rzadko i niechętnie. W domu też bywał zazwyczaj milczacy, a sprawy służbowe załatwiał krótko ${ }^{18}$. Skromność nie utrudniła mu jednak pracy naukowej, której rezultaty wydaja się po dziś dzień znacznie ważniejsze niż towarzyska komunikatywność czy atrakcyjność.

Bertrand Russell tak opisał skromność i związane $z$ nia inne dyspozycje psychiczne swego przyjaciela, filozofa i matematyka brytyjskiego Alfreda Whiteheada:

Był człowiekiem o niezwykle szerokich zainteresowaniach, a jego znajomość historii zdumiewała. Miał zachwycające poczucie humo-

\footnotetext{
17 J. Pieter, Czasy i ludzie, Wydawnictwo Adam Marszałek, Toruń 1997, s. 184.

18 W. Okoń, Dawid, Wiedza Powszechna, Warszawa 1980, s. 37-38.
} 
ru i wiele łagodności. [...] Jego zdolność do koncentracji przy pracy była niesłychana. Pewnego upalnego dnia, kiedy przebywałem u niego w Grantchesterze, zjawił się nasz przyjaciel, Davies Crompton, którego zaprowadziłem do ogrodu, aby przywitał się z gospodarzem. Whitehead siedział, pisząc coś z dziedziny matematyki. Davies i ja zatrzymaliśmy się przed nim w odległości nie więcej niż jarda i patrzyliśmy, jak pokrywał znakami stronicę za stronica. W ogóle nas nie zauważył i po pewnym czasie odeszliśmy $z$ poczuciem podziwu i respektu. Ci, którzy dobrze znali Whitecheada, dostrzegali w nim wiele rzeczy, które nie ujawniały się przy powierzchownym kontakcie. $Z$ pewnością nie był owym nadludzkim potworem, „człowiekiem rozumu”. Jego przywiąanie do żony i dzieci było głębokie i żarliwe. [...] Był równocześnie człowiekiem bardzo skromnym, a jego największa przechwałkę stanowiło to, że usiłował znać zalety swych wad. Nigdy też nie wzdragał się przed opowiadaniem niekorzystnych dla siebie historii. [...] Był nad wyraz doskonałym nauczycielem. Wykazywał osobiste zainteresowanie tymi, z którymi miał do czynienia, i znał zarówno ich mocne, jak i słabe strony. Wydobywał z ucznia wszystko, na co go było stać. Nigdy nie był mściwy, sarkastyczny czy wyniosły ani w ogóle taki, jakim chętnie bywaja nauczyciele „niższego rzędu”. Przypuszczam, że we wszystkich młodych ludziach, $z$ jakimi się zetkną, wzbudzał tak samo jak we mnie, bardzo rzetelne i trwałe przywiazanie ${ }^{19}$.

Maria Skłodowska-Curie cierpiała $z$ powodu tego, że świat chce ją widzieć inna niż jest - pisała Ewa Curie. Była na tym punkcie tak wrażliwa, że nie umiała do końca życia przybrać żadnej z owych sztucznych postaw, jakie wielkim ludziom na ogół narzuca sława. Obca pozostała jej zarówno zdawkowa uprzejmość, jak i poufałość wobec nieznajomych, zarówno poza surowości, jak i skromność na pokaz. Jej córka Ewa Curie wyznała:

Ja nigdy nie widziałam w niej [...] słynnej uczonej: zapewne dlatego, że myśl o własnej wielkości i sławie była dla Marii Curie czymś dalekim i nieważnym. Długie lata kariery, zarazem niezwykle ciężkiej i nad podziw świetnej, nie zdołały ani zwiększyć, ani obniżyć wartości jej charakteru, nie uczyniły jej duszy ani „mniejszej”, ani bardziej wzniosłej. Nawet w ostatnim dniu życia była jak zawsze łagodna i uparta, nieśmiała i ciekawa wszystkiego, co ja otacza. Taka sama, jak w poczatkach swej pracy, kiedy jeszcze nikt o niej nic nie wiedział. Obraza byłby przeto w stosunku do niej uroczysty pogrzeb, jakim świat czci zazwyczaj swych „wielkich” zmarłych. Pochowana została w największej prostocie i ciszy na wiejskim cmentarzu, pośród drzew i kwiatów. Tak

19 B. Russell, Autobiografia 1872-1914, Spółdzielnia Wydawnicza „Czytelnik”, przeł. B. Zieliński, Warszawa 1996, s. 190-193. 
właśnie, jak gdyby jej życie było podobne do tysiąca innych ${ }^{20}$. Albert Einstein mówił o niej: „Pani Curie jest - ze wszystkich ludzi na świecie - jedynym niezepsutym przez sławe człowiekiem. Szła przez swe zdumiewające życie prosta i nieskazitelna ${ }^{21}$.

W marcu 1904 roku Maria Curie w pełnym goryczy liście do Józefa Skłodowskiego pisała:

Bardzo nam się życie popsuło od czasu honorów i sławy. Zmęczenie spowodowane wysiłkiem, który przewyższał nasze siły, a który nam narzuciły złe warunki materialne naszej pracy, powiększyło się $z$ wtargnięciem sławy. Przełamanie naszego umyślnego odosobnienia było dla nas źródłem cierpień i miało katastrofalne następstwa. Ale nie tylko namiętna potrzeba pracy i lęk przed bezużyteczna stratą czasu sa źródłem tej odrazy małżonków Curie do rozgłosu. Piotr, jak wiemy, zawsze buntował się przeciw wszelkim odznaczeniom i hierarchiom; nie uznawał współzawodnictwa na polu nauki; nie rozumiał „ścigania się" $\mathrm{w}$ tym względzie, nie martwił się, kiedy go w jakiejś pracy ubiegli inni uczeni. [...] W zamian za to sława powinna była jednak przynieść państwu Curie - dodaje ich córka Ewa Curie - to, czego zawsze nieśmiało pragnęli jako ludzie nauki: katedrę, laboratorium, współpracowników - uczniów i kredyty na dalszą pracę naukową. Francja okazała się krajem, w którym ich wartość uznano najpóźniej: trzeba było dopiero medalu Davy'ego i nagrody Nobla, aby uniwersytet paryski zaczął się „krzatać" dokoła katedry dla Piotra Curie. Śmierć okazała się bardziej chyża niż władze uczelni. Dla obojga uczonych było to nad wyraz bolesne. Odznaczenia, które przyszły do nich z zagranicy, jeszcze mocniej podkreśliły fakt, że nad odkryciem nimi uwieńczonym musieli pracować w warunkach rozpaczliwych ${ }^{22}$.

Eugene Thebault w Petite Republique niezwykle trafnie uchwycił cechy charakteru Piotra Curie:

Chcę podkreślić pewna charakterystyczna cechę Pana Curie, a mianowicie jego głęboka bezinteresowność i wręcz doskonała skromność. Ten wysoki człowiek o niezwykle łagodnym spojrzeniu, który osiagnął sławę w młodym jeszcze wieku i którego ta sława zupełnie nie upoiła, ten uczony, mistrz, o jedno tylko się troszczył poza swą pracą i kręgiem swych rodzinnych uczuć. Pragnąłby, aby jego uczniowie i inni młodzi

${ }^{20}$ E. Curie, Maria Curie, przeł. H. Szyllerowa, Państwowe Wydawnictwo Naukowe, Warszawa 1983, s. 7 .

${ }^{21}$ Ibidem, s. 8.

22 Ibidem, s. 249-251. 
ludzie, którzy później zechca poświęcić się ciężkiej służbie Wiedzy, nie byli w zapale swoim hamowani przez opłakane warunki materialne. Zapominał o własnych przejściach i tylko o tym myślał, że może gdzieś żyją badacze godni uwagi, nieznani geniusze, którzy do niczego nie będą mogli dojść, ponieważ muszą zaniedbywać swoją pracę dla zdobycia utrzymania. A trzeba znać przekonania ich obojga: uważali mianowicie, że nadmiar zajęć dydaktycznych ze studentami lub uczniami to godziny skradzione pracy naukowej. Nikt nie mówił $z$ równą prostota, tak rzekłbym nawet, dobrodusznie jak Piotr Curie. Oto dlaczego zasługuje on i jego małżonka na coś więcej niż podziw $z$ naszej strony: ma on prawo do naszej powszechnej sympatii ${ }^{23}$.

Rafał Walzer wspomina $z$ kolei sylwetkę psychologiczna Edith Stein, filozofa pierwszej połowy XX wieku:

Była uosobieniem prostoty i naturalności. Pozostała [...] kobietą o subtelnej, macierzyńskiej wrażliwości. [...] nie miała w sobie nawet pozorów sztuczności czy wyniosłości. Była prosta z prostymi a uczona z uczonymi bez jakiejkolwiek wyższości; ponieważ sama była „otwarta”, każdy się przed nią łatwo otwierał. Praktykowała szczera krytykę, która jednak nie raniła, lecz dopomagała, gdyż nie podkreślała w kontakcie $z$ rozmówca swej wyższości, a zawsze szukała sposobów, w jaki mogłaby im pomóc. Nie istniało dla niej nic, co mogłoby ludzi dzielić. Usuwała na bok różnice społeczne i inne czynniki różnicujące ludzi [...]. Słowa o niej moga raczej zniekształcić niż ukazać jej charakter. Pierwsza śmiałaby się z przesady swych wielbicieli. [...] Na zewnattrz nic nie zdradzało głębi jej duchowego życia, chyba tylko doskonała harmonia między przymiotami serca i umysłu, powaga wobec problemów czasu i żywe zrozumienie - współczucie dla innych. Emanowały z niej przede wszystkim cisza i fuit et guiet (duchowy spokój) ${ }^{24}$.

Natomiast Jean Bering, profesor filozofii w Strasburgu, wypowiedział się o niej nastepujaco:

Miałem sposobność ocenić nie tylko jej uzdolnienia filozoficzne, lecz także jej cechy charakteru, np. umiała łączyć umiłowanie prawdy z miłością bliźniego, bezbłędną logikę wypowiedzi i dobre serce. Była dojrzałą osobowościa, w której dary naturalne, etyczne i umysłowe stopiły się w doskonała harmonię $e^{25}$.

\footnotetext{
23 Ibidem, s. 245-246, 208.

24 E. Stein, op.cit., s. 12-13.

25 Ibidem, s. 11.
} 


\section{Skromność - warunek egalitarnych relacji w środowisku akademickim}

W kontekście powyższych rozważań warto wspomnieć także o osobowości filozofa starożytności - Seneki, człowieka cenionego zarówno przez wówczas żyjacych, jak i przez współczesnych. Seneka posiadajacy głęboką niechęć do despotycznego stylu sprawowania władzy był kimś więcej niż doradca cesarza - starał się wychowawczo oddziaływać na Nerona i łagodzić jego niszczycielskie zakusy. Domagał się od niego tego, czego miał prawo oczekiwać od „dobrego" władcy. Nie litości, która jest czymś innym niż łagodność, ani darowania zasłużonej kary, lecz sprawiedliwego sądu, aby nawet wrogowie mogli zostać oszczędzeni, jeśli walczyli ze szlachetnych pobudek: $z$ obowiąku wierności, na mocy przymierza lub w obronie wolności. Seneka, który znajdował się wówczas u szczytu sławy, niesłychanie bogaty dzięki darom Nerona, które powiększyły jego własny majątek, znany był ze swej uprzejmości, ostro kontrastujacej $z$ ponura arogancja takich wyzwoleńców, jak Pallas. Uprzejmość i prostota Seneki były również cnotami stoickimi, które Panajtios zalecał mężowi stanu, wiążąc je $z$ wolnością. Działając tam, gdzie panuje równość praw, należało wyrobić w sobie przystępność oraz pobłażliwość. Skromność Seneki była więc obrazem pryncypatu wolności. Poznawszy nieco życie w Rzymie $z$ pewnościa cierpiał z powodu pychy „wielkich”, z którymi codziennie się stykał. Nie zawahał się jednak wybrać umiarkowanego sposobu życia. Mimo sukcesów oratorskich i adwokackich nie wyrzekł się filozofii i nie zrezygnował z praktykowanych wcześniej form życia wewnętrznego. Zachował na przykład zwyczaj przeprowadzania co wieczór swoistego rachunku sumienia, poddając krytycznej ocenie swa działalność. Nie poniechał też dobrowolnych wyrzeczeń, gdyż nigdy nie dowierzał swemu szczęściu ${ }^{26}$.

Filozof uważał, że słabe punkty zarówno w swej argumentacji, jak i stosowanych procedurach naukowych należy wykryć po to, by przyjaćc pozycję wyjściową do krytyki oraz dalszych starań. Bez przestrzegania owych norm, polegajacych przede wszystkim na szacunku dla interlokutora, na krytyce bez ranienia się nawzajem, dyskrecji nawet podczas wytykania sobie błędów, powstają silne konflikty, które powodują znacz-

26 P. Grimal, Seneka, Państwowy Instytut Wydawniczy, Warszawa 1994, s. 70, 130$131,204,55$. 
ne obniżenie wydajności pracy naukowej. Pracownik naukowy, poza ścisłym przestrzeganiem norm etyki zawodowej, powinien być człowiekiem skromnym, odważnym i życzliwym. Powinien tę życzliwość realizować we wszystkim, co czyni: ani chwili nie wahać się przed decyzja pozbawiajacca go dostatku lub sławy, jeśli za ów dostatek i sławę miałby zapłacić działaniem przynoszacym jego sumieniu większą szkodę niż pożytek ${ }^{27}$.

Za egzemplifikacje partnerskich relacji psychoterapeutycznych niech posłuży skromność Antoniego Kępińskiego, który:

[...] niechętnie mówił o sobie, do tego stopnia, że niewielu znajomych wiedziało o jego obozowej przeszłości. Nigdy nie powoływał się na szlacheckie parantele, choć „korzenie” jego rodu sięgały czasów Kazimierza Wielkiego. Był zdania, że o człowieku decydują wyłącznie własne osiagnięcia, nie pochodzenie lub majątek. [...] Współpracowników dzielił nie według stopni naukowych, ale według ich postawy i stosunku do chorych. Zwykle był jednak wyrozumiały dla wszystkich, pobłażliwy wobec różnych ludzkich słabości [...]. W kontakcie z pacjentem siebie umniejszał, a pacjentów wywyższał, przypisując sobie przeciętność, niezaradność, niezręczność, a innym siłę, sprawność, inteligencję i dobroć. Starał się dostrzegać w człowieku to, co dobre i dlatego pacjenci pięknieli także we własnych oczach i nabierali do siebie szacunku. Czasem mówił, że nie wiadomo, kto większe osiagga korzyści z psychoterapii: pacjent czy lekarz. $Z$ przekonaniem powtarzał, że to nie pacjenci winni mu płacić, ale on chorym, gdyż od nich wiele się uczy. Denerwował się, gdy jakiś terapeuta twierdził, że określony pacjent to banalny przypadek. Nie mógł zrozumieć, że człowiek może znudzić psychiatrę, kiedy dla niego samego kontakt $z$ chorym i związana $z$ nim sposobność, by podnieść kogoś na duchu, była rzeczywista przyjemnością. Może dlatego, kiedy go chowano, w uroczystych egzekwiach szło całe miasto, ale nad grobem panowała cisza, zgodnie $z$ wola zmarłego - nie było przemówieńn ${ }^{28}$.

Rozchwianie aksjologiczne we współczesnych społeczeństwach niesie za soba groźbę mutowania autorytetów naukowych w bossów „grup interesu" czy przedstawicieli zwalczających się frakcji. Zinstytucjonalizowanie form pracy naukowej wspiera pojmowanie nauki jako terenu starć konkurencyjnych stanowisk. Opozycyjność tego typu uniemożliwia asy-

27 J. Rudniański, Homo cogitans, Wiedza Powszechna, Warszawa 1981, s. 223, 228.

28 T. Lewandowski, Wstęp, w: A. Kępiński, Rytm życia, Wydawnictwo „Sagittarius”, Warszawa 1992, s. 6; Z.J. Ryn, Dekalog Antoniego Kępińskiego, Wydawnictwo Literackie, Kraków 2004. 
milację polimorficznego wzorca aktywności naukowej, polegającego nie tylko na przestrzeganiu zasady „jedności w różnorodności”29, ale wręcz poszukiwaniu różnorodności. Jeżeli w odbudowie takiego modelu nauki postrzegamy na pierwszym miejscu kwestię wspólnego dobra, wspólnego dzieła, wspólnego dziedzictwa czy też wspólnego uprawnienia, możemy powiedzieć, że naprawdę szanujemy naukę. Tylko dopuszczenie do głosu normy różnorodności w obszarze nauki nie grozi monolitem ideowym. Rygoryzm metodologiczny i merytoryczny zapowiada stagnację w nauce i autokratyczną sztywność w postawie uczonego - często wynikajace $z$ ksenofobi.

Doskonalenie intelektualne idace $\mathrm{w}$ parze $\mathrm{z}$ doskonaleniem moralnym uczonych zapowiada obiecujace rezultaty nauce. Postawa skromności nie wyklucza ani możliwości uznawania autorytetu innych, ani budowania własnego autorytetu. Autorytet naukowy powinien przyświecać przede wszystkim uczonym, którzy sa nie tylko nauczycielami innych pracowników naukowych czy studentów, ale wychowawcami w zakresie rozwoju uczuciowego i moralnego swych uczniów; przewodnikami w objaśnianiu rzeczywistości, transmisji wartości, takich jak prawda.

Autorytet można uznać za powszechnik kulturowy; nie ma nauki bez autorytetów, jak nie ma szkoły bez nauczyciela, a cechu bez mistrza. Autorytet jest konstytutywnym komponentem życia naukowego, nieodzownym innym uczonym, a poszukiwanie owych autorytetów wiele mówi o sposobie zakorzeniania młodszych uczonych w tradycji naukowej uniwersytetu ${ }^{30}$.

Autorytety stanowia zatem gwarancję zachowania w społeczności braterstwa, solidarności, tradycji, wyrażają także ludzkie pragnienie doskonałości. Podtrzymuja ład - rodzaj społecznego konsensusu - pod warunkiem, iż reprezentuja zgodność zasad współżycia społecznego z uznawanymi wartościami i normami działalności naukowej.

Postawa pokory utożsamiana ze zdolnościa do autorefleksji okazuje się nie tylko źródłem poszanowania godności każdego człowieka, ale przeciwwaga autokratyzmu i autorytaryzmu. Chodzi jednak nie o pokorę

29 J. Goćkowski, Autorytety świata uczonych, Państwowy Instytut Wydawniczy, Warszawa 1984, s. 102.

30 Ibidem, s. 26, 34. 
jako podporządkowanie się innym ludziom, ale pokorę wobec majestatu życia. Sugestywność jest wynikiem niedoborów rozwoju duchowego, cechą, która wiodła, jak potwierdza doświadczenie dziejowe ludzkości, do emocjonalnej zależności od władzy innych - silniejszych członków grupy, nierzadko autokratycznych liderów. Postawa antydogmatyczna to postawa charakteryzująca się docenianiem wolności, wzniesieniem się ponad przyzwyczajenie, ponad partykularne wyobrażenia o nauce i rutynowy wzorzec jej „uprawiania”. Najbardziej naukowe sa więc nie tak zwane powszechnie obowiąujace koncepcje i teorie, ale metodyczne watpienie - autorefleksyjna postawa badawcza. Ludziom ceniacym takie jednostki wartości, jak wolność czy wdzięczność, z pewnością łatwiej dotrzeć do pokładów swej kreatywności i uczynić z niej sensotwórczy styl życia.

\section{Podsumowanie}

Skromność pracownika naukowego, aby stała się atutem, a nie utrwalona nieśmiałością, powinna wiązać się z akceptacją własnej postawy emocjonalnej. Skromność wynika przede wszystkim z właściwego postrzegania ludzkich ograniczeń i możliwości, mądrego korzystania $z$ własnej inteligencji i twórczych zasobów umysłu, braku przeciwstawiania swoich osiagnięć nieudolności innych. Postawą skromności charakteryzuja się uczeni, którzy pracuja nie tyle dla własnych profitów, ile dla celów ponadosobistych, mają świadomość społecznej służby, czyli działalności w znacznym stopniu bezinteresownej i humanitarnej.

Człowiek skromny ma wielka przewage nad zbyt pewnym siebie, zwłaszcza w dziedzinie nauki; skromny sprawdza wszystkie możliwe rozwiązania i w rezultacie nie pominie żadnego. Nieskromny nawet nie bierze pod uwagę tego, że ktoś może być sprawniejszy w pracy naukowej. Sądzi, że nie ma konkurentów i dlatego nie inwestuje w swe badania dostatecznie dużo wysiłku. Niedobory skromności moga stanowić zatem czynnik blokujacy (inhibitor) rozwój naukowy. Tytuły, stopnie naukowe i wyróżnienia, które otrzymuje człowiek skromny, są na ogół konsekwencja jego pracowitości i talentu naukowego, nie koligacji. Uznanie społeczne wprawdzie wzmacnia rezultaty jego pracy, ale nie sprawia, że traci zdolność do autorefleksji i samokrytyki, czy zaprzestaje profesjonalnego doskonalenia (vs samodoskonalenia). Wie bowiem, że za sprawa swej 
świetności zyskiwać powinien nie tyle on sam, ile dziedzina nauki, która reprezentuje. Postawa skromności sprzyja zatem wyborowi optymalnego stylu pracy naukowej - prowadzącego do znaczacych odkryć.

Słowa kluczowe: skromność, rozwój naukowy, pracownik naukowy, osobowość, autorytet, postawa

\title{
THE ATTITUDE OF MODESTY - A FACTOR DYNAMIZING SCIENTIFIC DEVELOPMENT
}

\begin{abstract}
Summary
On the basis of own biographic studies conducted between 2007 and 2009 and continued from 2013 to 2015 (analyses and interpretation of 70 biographies and autobiographies of known researchers), I proposed in my article and justified a thesis that among the main factors dynamizing individual scientific development, apart from intellectual attributes, are personality traits such as modesty. Scientific development is fuelled mainly by values and the related character (or personality) traits of the researcher. I also put forward an assumption that scientific development of researchers contributes to the progress in science understood as a sphere of culture. The attitude of modesty - the antonym of pride and megalomania is then especially required of a researcher and proves his or her predisposition to discovering the truth and to communicating the research results in an honest manner. Modesty also helps one choose an optimal style of research, which in turn leads to considerable discoveries.
\end{abstract}

Keyword: modesty, scientific development, researcher, personality, authority, attitude 